\title{
THE SELECTION FACTORS OF CONSULTANTS IN SERBIAN AGRO-SECTOR ${ }^{1}$
}

\author{
Branko Mihailović2 ${ }^{2}$ Boban Birmančević ${ }^{3}$, Miloje Obradovićc
}

\begin{abstract}
Summary
The selection of consultants should be paid special attention, because in Serbia, or its agro-sector, the awareness of the criteria for the selection of consultancy services is not sufficiently raised. The research itself is based on the assumption of manager experience and knowledge gained by reading expert books, greeted with scepticism. Thus, the relevance of certain criteria for the consultant selection is in the form of a hypothesis, with the aim to determine the real situation in this field. Determination of consultant selection basic factors in Serbia is imposed by the law of nature. The process of selecting a consultant starts with defining the requirement of the consultancy task and criteria for the degree of performance of the task. This process usually leads to the reference list that a consultant is supposed to have.
\end{abstract}

Key words: consultant selection criteria, consulting organizations, quality management system, agro-sector.

JEL: $M 21, Q 13$

\section{Introduction}

The managers in companies spend most of time and expend considerable energy in identifying and analysing business problems, tending to find efficient solutions. Internal management teams solve the most of problems in the field of management within daily routine activities. One's a problem is solved, there appears the other on which should focus and this is the way

1 The paper represents a part of the research at the project III 46006 - Sustainable agriculture and rural development in terms of the Republic of Serbia strategic goals' realization within the Danube region, funded by the Ministry of Education, Science and Technological Development of the Republic of Serbia.

2 Branko Mihailović, Ph.D., Scientific Associate, Institute of Agricultural Economics, 11060 Belgrade, Volgina Street no. 15, Serbia, Phone: +381 1129728 58, E-mail: brankomih@neobee.net

3 Boban Birmančević, M.Sc.ecc, Telekom Srbija a.d., Coordinator of execution unit, Belgrade region - Execution unit Šabac, Karađorđeva street no. 10, 15000 Šabac, Phone: +381 6465110 00, E-mail: bobanb@telekom.rs

4 Ass. Professor Miloje Obradovic, Ph.D., the School of Engineering Management, Bulevar Vojvode Misica 43, 11000 Belgrade, Serbia, Phone: +381 6482343 66, E-mail: mobradovic@slglasnik.com

EP 2014 (61) 1 (149-162) 
business perform. However, there appear also non-structural problems on which cannot be applied routine solutions. They become a subject of serious consideration. Often happens that managers avoid them, or talk about them, but no decision has been made.

Causes for such business problems are numerous and often mutually interweaved. It is usually about innovations, ambiguities, complexity, fast changes of problem essence and size, conflict of interest, long-term impacts to future business, etc. In some situations is more purposeful to engage a consultant to solve such problem, but to spend time and assets while searching the solutions which exceed the company's capacity. Some managers do not identify the business problems and arguments „pro“ and „con“ use of consulting services, but are guided by a feeling that a consultant can do a job.

On the other hand, a decision on using the consulting services can be emotionally coloured, if a manager is impressed by broad knowledge and professional approach of a consultant. Nevertheless, the managers have to be pragmatic. Accordingly, the managers must have characteristics like: creativity, innovativeness, imagination, high motivate, leadership, as well as a practice to communicate verbally and in written form. In order to manage the company successfully, the manager must have self-confidence, ability of quick troubleshooting, planning, business skills, skills in relationships and awareness on personal virtues and deficiencies (Sajfert et al., 2008).

If the manager is serious in attention to use the consulting organization, he primarily wants to be sure if his decision will be completely justified and supported within the company, that there will be selected adequate consulting organization and that the company will have clearly defined positive effects from a consulting project.

Taking into consideration the criteria of selecting the consultants, analysed by famous researcher and consultant in this field (Kubr, 1995), in this paper has started from the following hypothesis: Decisive criteria for selecting the consultant in Serbian agro-complex, by the hierarchy, are: professional integrity, professional qualification, capability for doing business, price of consulting service, cooperation and relation with clients, project task draft, potential for mobilizing additional resources and a reputation/image of the consultant.

\section{Researching method}

This paper's goal is to determine the most important criteria of consultants' selection in agrocomplex of Serbia, in order to improve the process of consultants' selection and, at the same time, make the assumptions for adequate consulting services to the companies.

Empirical check of the set hypothesis was made by the procedure, by which achieve relevant conclusions for science - by research of field data, more concrete, by collecting adequate data on sample of 80 agrarian companies in Serbia, according to which are possible to make appropriate conclusions and generalizations, and the structure of the researched samples was striving to the structure of the total agro-complex in Serbia.

By the sample were comprised the companies which represent representative basic set population units, as: PKB Corporation - Padinska Skela, Soko Stark - Belgrade, Centroproizvod 
- Surcin, PIK Becej, Karneks - Vrbas, Si\&Si Group, AD Dragan Markovic - Obrenovac, etc.

The survey of the market research was done by three techniques: 1) telephone survey, 2) direct interview and 3) electronically.

In realization of the research task was used also a desk research of data, which refer to the criteria of consultants' selection, which was a valuable support in setting a research hypothesis. With combination of the mentioned research methods can get more reliable answer to key questions, which impose themselves within the factor analysis of consultants' selection in agro-complex of Serbia.

\section{Researching results}

The companies of agro-complex of Serbia from a sample were surveyed to determine the importance level of the following criteria, on a scale of 1 to 5 (1-the least important criterion for selecting the consultant, 5-the most important criterion for selecting the consultant):

Table 1. Evaluate your basic criteria while selecting a consultant

\begin{tabular}{|l|l|l|l|l|l|}
\hline \multicolumn{1}{|c|}{ Criteria for selecting consultants } & $\mathbf{1}$ & $\mathbf{2}$ & $\mathbf{3}$ & $\mathbf{4}$ & $\mathbf{5}$ \\
\hline Professional integrity & & & & & \\
\hline Professional qualification & & & & & \\
\hline Cooperation and relationship with a consultant & & & & & \\
\hline Project task draft & & & & & \\
\hline Capability for doing business & & & & & \\
\hline Potential for mobilizing additional resources & & & & & \\
\hline Price of consulting services & & & & & \\
\hline Image of a consultant & & & & & \\
\hline
\end{tabular}

Source: Research of authors, 2013

According to estimated importance of some criteria for selecting a consultant, their order, by importance hierarchy, would be:

Table 2. Hierarchy of the criteria importance in selecting the consultants in Serbian agro-complex

\begin{tabular}{|l|r|}
\hline \multicolumn{1}{|c|}{ Criteria in selecting a consultant } & \multicolumn{1}{|c|}{ Average grade } \\
\hline Professional qualification & 4.8 \\
\hline Capability for doing business & 4.6 \\
\hline Professional integrity & 4.4 \\
\hline Image of a consultant & 4.3 \\
\hline Cooperation and relation with a consultant & 4.1 \\
\hline Potential for mobilizing additional resources & 3.8 \\
\hline Project task draft & 3.5 \\
\hline Price of consulting services & 3.4 \\
\hline
\end{tabular}

Source: Research of authors, 2013 
The companies in agro-complex of Serbia agree in one: the issue of consulting services prices cannot be more important than the professional integrity and the professional qualification of a consultant. On a scale from 1 to 5 ( 1 - the least important criterion for selecting a consultant; 5 - the most important criterion for selecting a consultant), the price of a consulting service has the lowest average grade (3.4), opposite to the professional qualification with the highest grade (4.8). The results of empirical research coincide with recommendations of some international consultants associations. For example, the International Federation of Consulting Engineers - FIDIC, recommends to the clients to select a consultant according to capabilities, not price. Of course, the empirical research results should not be interpreted in a way that the price of the consulting service is irrelevant, but it can be taken into consideration only in the second round of a consultant's selection, and only those who fulfil the criteria of the business qualification and integrity.

Professional integrity - The selection of a consultant can be a simple process, if it is about hightechnological problem, which is easy to determine and if it is about the field in which are one or more experts, which should be engaged. However, the consulting projects in management differ, as a rule, from this situation. It is certain that more consulting organizations of different profile, different size and with different background, will be interested for participation in selection procedure. At the same time, there apply also professional organizations from other sectors, because they had expanded their activity and had started actively to be engaged in business consulting. Although is hard to define a final product of the consulting service and it is not secure in advance, uncertainty can be diminished, and chances for getting a satisfactory product can increase in a way to select:

- Professional organization, well known by providing a first-class service,

- Individuals employed in that organization, which own acceptable technical expertise, with which can cooperate and which can be trusted that will achieve a mutual goal,

- Defined project task, which will, according to consultants and clients, will give the best results,

- Various logistic, organizational, financial and other conditions, which will facilitate these goals' achievement (Kubr, 1995).

The standard or universal criteria for selection of a consultant do not exist. It is important to point out that a client is the one who chooses a consultant, not vice versa, even if can impact to the potential clients by very sophisticated and direct marketing. There is also necessary to harmonize a volume of time and effort spent on searching the consultant and making the selection with complexity and importance of a business problem.

If there is a characteristic which distinguishes the consulting service and points out their difference in regard to other commodities and services, it is neither providing advices nor technical expertise, but the professional integrity, which is necessary condition for selection of a consultant. Numerous issues will be solved and problems avoid, if never makes a compromise about ethical standards and integrity. Certain information on professional behaviour of consulting organizations circulates in clients' circles, and, at the same time, this question which can be put to ex-clients (references). Some situations require an open 
discussion, as a risk of conflict of interest, as by a consultant, as well as by a client. Other questions must not ask directly, since a consultant will reveal much while he talks about his performances, consulting profession, clients, competitiveness, etc. The consulting services play a certain role in economic and social life if ethical standards permeate all phases of the consulting process, as well as relations with clients. If this principle does not respect or sacrifice with a consultant's economic interests, the provided consulting service cannot be professional and independent. Consequentially, it is needed to know what the consulting organizations imply under professional behaviour. Necessary information can obtain from the consulting associations, because all associations have ethical codes and professional codes of conduct. Hereinafter will be considered the professional standards which use in consulting profession.

The initial condition for professional behaviour of a consultant and respect of a client organization's interest is providing true information on a consulting organization. It is necessary that the clients subject such information to a meticulous analysis and to ask for additional information, if they are not satisfied. The clients expect from a consultant a professional opinion, even if it differs from what they want to hear. Impartiality of a consultant means that he must not be engaged in internal policy of the company. At the same time, a consulting service should not be coloured by prejudices or emotions. General principle in consulting work is that the professional consultants must not give or receive any commission fee in order to get the project or to give presents related to the consulting project. If a consultant is engaged, it is understandable to expect that he will not announce any confidential information on a client, nor will use such information for gaining benefits. Without confidentiality, there will be neither consulting services, nor the consulting as a profession.

Generally, it is hard to make comparison of consulting services' products with other products, and it is possible that a consultant is the only person who knows how much effort and time is really needed for realization of the consulting project. Therefore, an issue of adequate compensation is, substantially, a question of professional integrity, i.e. ethics. Closely related to this professional standard has been also avoiding the conflict of interest, while the clients and their professional consultants have been complex organizations which have wide range of economic and social activities. Accordingly, there form the consulting associations, which define codes of conduct for their members.

The research of the consulting services' market in Serbia was determined that there is a significant demand for the consulting services regarding production standardization, in agro-complex (Mihailović, 2011). In accordance with the company's needs in the Serbian agro-complex, it seems suitable to formulate certain directives for selecting a consultant in this field, and especially for realization of quality management system.

In implementation of the quality management system, some companies in the agrocomplex of Serbia decide to lean upon their own personnel, but some use services of external consultants. Selecting a consultant is important for the organization, because it should provide that the resulted quality management system to be able to fulfil all 
aims, which the organization had planned in the best and effective way. Even when use a consultant's services for the quality management system, inclusion and devotion of top-management of the organization are key factors for realization of the quality management system. This international standard is meant for providing guidelines regarding the factors, which should consider when a consultant selects for the quality management system. It can be used by the organizations for the quality management system when selecting a consultant capable to fulfil their special needs, expectations and goals in realization of the quality management system. It also can be used by: a) consultants for the quality management system, as the guidelines for consulting on the quality management system, and b) consulting organizations, for selection of a consultant for the quality management system (Directives for selecting a consultant for the quality management system and using their services, 2005).

In accordance with the requirements of the professional integrity criteria, the companies in agro-complex should consider the following moral rules when select a consultant for the quality management system. A consultant should:

- Avoid or report any conflict of interest regarding a business which should be done,

- To save information confidentiality, got or taken from the company,

- To protect his independence from certification bodies/registration of the quality management system or the accreditation bodies,

- To protect impartiality when selecting the certification/registration body by the organization,

- To provide a real costs evaluation for consigned consulting services,

- Not to make unnecessary dependence from his services,

- Not to offer his services if he has no necessary qualification.

Professional qualification - Competitiveness sustainability on fast-changing market of the consulting services requires adequate education and continuous training of the consultants. Education for changes is an imperative for harmonization between society development and modern trends. Globalization and fast development of new technologies have caused new approach to education. Besides series of factors, of which depend development and economic progress of the society, three factors can mark as extremely important: permanent education; efficient introduction of new technologies; preservation of natural resources (Arsić, Savić, 2005).

The qualification criterion is, in most of the cases, a necessary condition for a consultant's selection. Only the consulting organizations, which show necessary qualification can be included in a shortlist and assessed according to other selection criteria. These criteria have the highest average grade in accordance to the surveyed companies' replies in the agrocomplex of Serbia.

In order to be sure that the problem of a consultant's qualification has been adequately considered, the companies in agro-complex have to answer to some questions, which relate to specific qualification aspects (Kubr, 1995). 
Firstly, there must evaluate the consulting organization's and an individual consultant's qualification. During the consulting organization selection purchases just its qualification, where personal qualification of a consultant cannot be equal to the consulting organization's qualification. In regard to it, it is logical to ask a question: "How the consulting organization manages, supports and controls its consultants in the field and how it ensures quality?"

In situation when it is about the consulting project of system development or methodology, which the consulting organization had previously implemented in other companies and for which it can offer some standardized model or its draft, a junior consultant is usually sufficiently qualified for doing business, of course, with support and supervision of more experienced consultant. On the other hand, if it is about the consulting project which implies evaluations and selection of alternatives in unprecedented situations, the consulting organization will have to determine a consultant with more professional experience, who will be relatively independent of the consulting organization management, but to whom will be available the organization's resources, when needed.

The companies in agro-complex of Serbia have to consider if there is necessary for the concrete consulting project that a consultant knows in detail a branch in which a client is, i.e. in which the company does business. Some consulting organizations have sectored specialized for: industry, agriculture, construction, insurance etc. At some, there is present, so called, functional specialization for marketing, organization, finances, personnel, etc. A consultant, skilled for some branch, can have an advantage when it is about a wide range of the consulting projects, which refer to a business strategy, restructuring, business and marketing. This specific knowledge is less important for managing personnel and finances, if a consultant is willing to learn fast on sector's characteristics and its differences in regard to other sectors in which he was engaged.

Of crucial importance is to examine knowing country and culture of a client, if a consulting project requires engagement of a consultant from abroad. The consultants are aware of a role and significance of environment for professional business performs and they are very sensitive to economic, political, social, cultural and other factors. In situation when a consultant starts a project in a country new for him, it is unrealistic to expect that he knows local conditions. Often happens that the consulting organizations follow the companies and the banks in business internationalization. It is understandable, since the partners, i.e. the foremost and the most competent consultants, are carriers of the most actions in multinational and national organizations. Coming to new countries requires additional research, analyses and the consultants' preparations. However, if there is needed an advice from a highly-competent consultant for exceptionally specialized field, it is counterproductive to require in depth acquaintance with a client's country and culture.

The most of the consulting projects today have impact to, so called, ,hard“ and ,soft" skills of a consultant. Hard skills imply a consultant's capability to understand and use in his work procedures, systems and methods which can be formally structured, described and quantified and which can be easily carried over to men of adequate knowledge, acquired by education. These skills are necessary in every field of consulting, but the most needed in 
management and financial analysis, managing processes in production and services sectors, information systems and logistics. Soft skills refer to values, attitudes, emotions, relations and forms of human behaviour. These skills are necessary for understanding and influence to interpersonal relationships in the company, motivating the employees and managing the changes which have an impact to interests and emotions of employees. Accordingly, when selecting the consulting organization, it is important to focus to a relative value of hard and soft skills for realization of a specific consulting project. That is to say, a consultant can be expert in his field, but at the same time non-empathic and incapable to cooperate with people. Even so, a modern consulting, as a profession, has significantly developed in terms of balancing hard and soft skills, all in order to adjust business offer to the specific needs of the companies.

Societies with developed agriculture and efficient institutions have timely noticed the importance of knowledge, as a significance factor of agricultural production modernization and until now have relatively successfully enabled their transfer to the final users (Petrović, Čikić, 2005). Of course, the transfer of knowledge depends on a type of a consulting project. Some projects require high level of creativity and innovation, while some of them represent rather routine activity. Also, the important question is whether a consultant did earlier a similar project for some other company, although this fact should not be a reason for a consultants selection. If there is needed an innovative solution, there becomes prominent a consultant>s ability to judge creatively, not conventionally, to apply the research methods and models of IT and, accordingly, to generate new business ideas.

Taking into consideration that, in the Serbian agro-complex, there is a great demand for the consulting services in the field of introduction and implementation of standards in production and quality management, there will consider needed professional qualification of the consulting organization for this type of the consulting project. Factors of its professional qualification represent more developed and partly modified form of previously mentioned determinants of a consultant's qualification. When a consultant selects for the quality management system, the organization should value if a consultant has the qualification, suitable for size and content of consulting services he ought to provide. The qualification has been defined in ISO 9000 as the shown ability for applying knowledge and skills. As such it encircles: personal characteristics; education, knowledge and skills; knowledge and skills specific for the organization; working experience; improvement of qualification (Directives for selecting consultants for the quality management system and using their services, 2005).

Price of a consulting service - The companies in the agro-complex of Serbia agrees in one: the issue of consulting services' prices cannot be more important than the professional integrity and the professional qualification of a consultant. A consultant, as a rule, forms a price and collects a service in accordance with the usual practice in profession, where a method of collection of the consulting services negotiates before the business starts. If the price deviates (lower or higher) from the usual market price, then it is necessary to inform a client with the reasons of deviation. 
The analysis of the required prices often opens a question of the project task type and personnel needed for its realization, so it should also be considered and specified at the very beginning. In that way, at the beginning will eliminate undesirable occurrences, which can seriously disturb the established good relations between a consultant and a client, and the smallest misunderstandings can disturb realization of the agreed job.

During the analysis of a consultant's offer, before it accepts it, management of a companyclient pays special attention to if it is correct, testing primarily if it contains some unnecessary, and therefore, unfavourable items:

- Consultant suggested an expensive approach (e.g. too broad data collection, used more samples than necessary, elaboration of too many alternatives, purchase of expensive patent systems or equipment - hardware, etc.),

- project proposal anticipates the engagement of highly-educated and high-priced experts (a larger number of senior consultants) than necessary in that case,

- Consultants suggest their people for activities a client can do by himself or with little training and directions (Kubr, 1995).

Of course, if the offer contains such elements, it refuses smoothly, or, by negotiations, comes to optimal solutions, which will make mutual satisfaction, because only in such an atmosphere, the cooperation can be successful. For successful realization of a consulting task is very important to make an optimal team selection. The consulting task complexity level dictates a number and a structure of a team. As a rule, simpler jobs, concerning one or two functional fields, assign to one or several executive (field) consultants-experts for the specific fields (Blečić, 2005). To a leading consultant assigns the supervision of the executive consultants and he can be responsible for several consulting projects simultaneously.

That is to say, a leading consultant must not be permanently present in a company-client, but from time to time he visits the executive consultants, monitors the consulting task's progress and helps them with suggestions. In situations when it is about a complex consulting project, there makes a different selection of a consulting team. A role of a project manager has a consultant-analyst, who had done a report on company business analysis and he was the most deserving for a project negotiation. Since he has spent the most of time in a companyclient, he is the best familiar with the situation, management of a client trust him the most. On the final price of the consulting service significantly affect a planned profit level of the consulting organization and to this purpose use several important parameters (Kubr, 1976). When planning a profit, the consulting organizations use a profit-income ratio. The ratio between 0.1 and 0.2 considers normal, but it depends on great number of factors. Real size of a profit which the consulting organization can realize, before tax, depends on taxation level and need to allocate funds for investments. If the consulting organization is in development process, which it has to finance with own funds, there can be needed a higher profit due to re-investing in business.

On the occasion of budgeting and planning the consulting organization work, there are more ways to realize higher profits. The management has to consider which method will adopt, depending on the market, possibilities for recruiting new consultants and abilities to improve an internal organization and activities planning. 
Thereby should have in mind that all services that provide do not make profit. For example, certain number of working consultants and one senior consultant (consultant for special researches) can do the consulting project completely, while the rest of the senior consultants engage in preliminary researches and supervision functions.

Other criteria for a consultant's selection - Due to more complex image, selection of the consulting organization can observe in context of alternative actions for the changes project initiation (Table 3). Theoretical model, which explains this phenomenon, is, so called, Lundberg model, which represents a process of sequential selections series. The model has a form of series of questions for a manager - actor of organizational changes. The answers to the questions (by adequate order) lead to a decision on a method of initiating the organizational changes (Cvijanović, 2004).

The answers are, in fact, the rules which determine particular behaviours (selections) which lead to a next selection and so on, until defines the total path, i.e. a mode of initiating the organizational changes. The Lundberg model contains:

$\Rightarrow$ Set of alternative actions selection for the organizational changes initiation ( $Y s$ in table 3) where $\mathrm{Ys}=\mathrm{Y} 1, \mathrm{Y} 2, \mathrm{Y} 3, \ldots, \mathrm{Y} 7$;

$\Rightarrow$ Set of contingent questions or rules (Xi in table 4), where $\mathrm{Xi}=\mathrm{X} 1, \mathrm{X} 2, \mathrm{X} 3, \ldots, \mathrm{X} 10$;

$\Rightarrow$ Function of branching which converts conditions vectors in questions choice, i.e. $\mathrm{Y}=\mathrm{F}(\mathrm{X})$.

The model has seven different selections of action on its way out (Ys in table 3), sort independently from their phenomenon frequency on model way out and which, according to Lundberg, cover the most of possible actions on initiating the organizational changes. The model contains ten contingent conditions (see $\mathrm{Xi}$ in table 4). Every $\mathrm{Xi}$ is, in fact, a question on which should answer with ,yes“ or "no", which means that Xi takes a value "O" and " 1 ". The function of branching $\mathrm{Y}=\mathrm{F}(\mathrm{X})$ is derived induction from experiences of successful managers - actors of changes.

Table 3. Alternative actions of the project changes initiation

\begin{tabular}{|c|l|}
\hline Y1 & Nothing to undertake \\
\hline Y2 & To solve (manager directly applies his solution to the appeared problem) \\
\hline Y3 & $\begin{array}{l}\text { Problem passes to a higher level, due consideration that it could be solved only at the higher } \\
\text { level, while it exceeds his authorities scope }\end{array}$ \\
\hline Y4 & $\begin{array}{l}\text { Forming ad hoc committee (the committee is defined as a set of the manager's colleagues or } \\
\text { subordinates, whose task is to suggest a solution to the manager, i.e. they are not authorized for } \\
\text { implementation) }\end{array}$ \\
\hline Y5 & $\begin{array}{l}\text { To obligate the Standing Committee to suggest possible solution to the manager (the Standing } \\
\text { Committee exists from earlier and deals with problems and activities regarding the concrete } \\
\text { problem, which solve the manager) }\end{array}$ \\
\hline Y7 & $\begin{array}{l}\text { To form a working group - team (task force is defined as a group colleagues responsible, by the } \\
\text { manager, for the solution suggestion, but also their implementation) }\end{array}$ \\
\hline $\begin{array}{l}\text { To make a contact with consultants (a consultant is a man outside the organization who is agreed } \\
\text { to,supply“ the manager with recommendations) }\end{array}$ \\
\hline
\end{tabular}

Source: Lundberg, 1990; 
The Lundberg model is interesting for conditions and opportunities in Serbian agrocomplex. The total role of a manager in our companies gets its significance, even the part of his role oriented toward the organizational changes, as a response to the problems occurred in the company and its business environment. The Lundberg model has been extremely focused on selection conducted by a manager and to a practice in which the incurred business problem has immersed.

Table 4. Xi: Contingent conditions in form of questions

\begin{tabular}{|c|c|}
\hline $\mathbf{X 1}$ & $\begin{array}{l}\text { Is it necessary to initiate the project changes (X1 represents a manager's opinion whether a } \\
\text { discrepancy will disappear if it is ignored) }\end{array}$ \\
\hline $\mathbf{X} 2$ & $\begin{array}{l}\text { Does a manager know technically feasible solution or a project (design), } \mathrm{X} 2 \text { does not include } \\
\text { managerial evaluation of the project/solution acceptability by his subordinates. }\end{array}$ \\
\hline $\mathbf{X 3}$ & Does a manager have time to solve or project the discrepancy solutions? \\
\hline $\mathrm{X} 4$ & $\begin{array}{l}\text { Is a manager authorized to solve or to project the discrepancy solution? (X4 refers to a manager } \\
\text { capable to determine, and not refers to a manager's ability to choose technically possible } \\
\text { solution - project) }\end{array}$ \\
\hline X5 & $\begin{array}{l}\text { Is the discrepancy repeats (X5 asks a manager is it possible the discrepancy occurs again or } \\
\text { was noticed earlier) }\end{array}$ \\
\hline X6 & $\begin{array}{l}\text { Will a manager's solution/project be accepted or there should negotiate on acceptance? } \\
\text { (Manager's negotiation ability depends on his capability to identify men who will be affected } \\
\text { by the project changes, as well as of his relative power among them) }\end{array}$ \\
\hline $\mathbf{X} 7$ & $\begin{array}{l}\text { Can a manager carry out the discrepancy to his superior? (X7 depends on manager's assessment } \\
\text { of his will and attention to carry out the problem to his superior one and the superior's will to } \\
\text { accept it) }\end{array}$ \\
\hline $\mathbf{X 8}$ & $\begin{array}{l}\text { Is there appropriate Standing Committee and is there enough time to respond? (X8 depends on } \\
\text { a manager's confidence in the Standing Committee's competence) }\end{array}$ \\
\hline X9 & $\begin{array}{l}\text { Is it possible to contract a consultant? (The possibility depends on a consultant's availability, as } \\
\text { well as of the resources for compensation of a consultant's effort) }\end{array}$ \\
\hline $\mathbf{X 1 0}$ & $\begin{array}{l}\text { Is there a serious time limit or a dead end? (X10 requires a dictate of the solution/project } \\
\text { solution, if a manager believes that there is no use of further discussion!) }\end{array}$ \\
\hline
\end{tabular}

Source: Lundberg, 1990;

Our managers haven't got used to think individually on the changes projects. For example, the organizational changes projects were common and mutual problem or a higher instance problem. It would be useful that the managers in companies in agro-complex study the Lundberg model, to use it to test their thought process of selection and to use it simulative, taking care on necessary time and needed financial resources. The Lundberg model had found a quite acceptable balance between standardization of selection procedure, on one hand, and a specific practical situation, on the other hand (Cvijanović, 2004). Completely situational specific models, which base on local theories, were not accepted by the organizational changes managers-actors. The Lundberg model is usable on every hierarchical level and is opened for personal improving and extensions, which a manager-successful practitioner finds necessary. Consequentially, size of a company is not an obstacle to this model implementation; although in big companies have more possibilities for their successful application. If previous selection 
model shows that there is necessary to use the consulting services, than can move to in depth analysis of criteria of professional integrity, professional qualification and the consulting services' prices. Except them, in a phase of valuation and consultant selection should involve few more criteria. According to advices of the consultant and research Kubr Milan, there is necessary to perceive also: previous experience with a consultant, forming the project task, capability for execution of a task, potential for mobilizing additional resources and a consultant's image (Kubr, 1995).

The conducted research has led to redefining of a starting hypothesis, first of all, to order correction of some criteria for consultants' selection by relevance (Mihailović, 2011). In accordance to it, there could conclude the following:

Decisive criteria for selection of a consultant in agro-complex of Serbia, by hierarchical order, are: professional qualification, capability to do business, professional integrity, image of a consultant, cooperation and relation with a consultant, potential for mobilizing additional resources, draft of a project task and a price of consulting services.

If starts from a theoretical abstraction that a company should select a consultant only according to one criterion, then, probably, previous experience with a consultant would be the safest. The relationship with a consultant is interpersonal relationship, not between organizations. However, there is no warranty that the same productive relation will develop between other people who will work at the project from the consulting organization and the client's organization. A key element of this relationship is trust. That is to say, a client expects that he will not be cheated by a consultant and that will not abuse his ignorance, absence, difficulties and lack of time for control. The consulting researchers mostly agree that it is not enough to select a consultant who is generally qualified (Kubr, 1995). Expertise of the consulting organization and an individual consultant must reflect in their approach to a project task. Analysis of a consultant's approach to a project task will reveal if a consultant makes efforts to understand completely a client's specific problem or to suggest application of one of the standard packages of his consulting organization. Evaluation of a project task can be done according to discussion with a consultant regarding a business problem and methods of their resolution, as well as by a formal proposal of a project task, submitted by a consultant. The consulting organization has to be capable to fulfil the promises. The capability to do business implies that professional staff be available at the right time, where logistics, support and supervision are also important. There happens that some consulting organizations compete for businesses they are not able to do independently. In such conditions, the companies can easily detect it by consideration of a project task proposal, by putting direct questions and informing on a consulting organization. The potential of mobilizing the additional resources is important criterion, too. Complex consulting projects require that, sometimes during their realization, goes beyond the project. The companies-clients have interest to know whether they will have to search for the additional resources for specialist advices in the field of market, engineering, law, etc. Finally, the easiest way in selecting a consultant is that a company addresses to a consulting organization with a good reputation, i.e. an image. It is a logical move for many inexperienced users of consulting services, which try to avoid risky situations. 


\section{Conclusion}

The companies in agro-complex of Serbia agree in one: the issue of consulting services' prices cannot be more important than the professional integrity and the professional qualification of a consultant.

The empirical research results coincide with recommendations of some international consultants associations, which recommend to the clients to make a selection of a consultant according to his capabilities, not according to price. Consequentially, the research results should not be interpreted as the consulting service price is an irrelevant criterion for selection, but it can be considered just in the second round of the consultant's selection and exactly of those which satisfy the professional integrity and professional qualification criteria.

Some projects require a great creativity level and innovations, while some of them represent rather routine activity. Also, the important question is if the consultant has been involved earlier in a similar project for some other company, although this fact must not be a reason for choosing the consultant. If there is necessary an innovative solution, there becomes prominent an ability of a consultant to judge creatively, not conventionally, to apply research methods and models of IT and, consequently, generates new business ideas.

It is important to emphasize that a client selects a consultant, not reversely; although on potential clients can be affected by very sophisticated and direct marketing. If a manager is serious in attention to engage the consulting organization, he primarily wants to be sure that his decision will be completely justified and supported within the company, that there will be selected the adequate consulting organization and that the company will have clearly defined positive effects from the consulting project.

\section{Literature}

1. Arsić, J., Savić, M. (2005): Edukacija - put u multifunkcionalnu poljoprivredu, Međunarodni naučni skup Multifunkcionalna poljoprivreda i ruralni razvoj, decembar, 2005, IEP, Beograd, str. 332-336.

2. Blečić, S. (2005): Međunarodna trgovina konsalting usluga, magistarski rad, Univerzitet u Beogradu, Ekonomski fakultet.

3. Cvijanović, J. (2004): Organizacione promene, Ekonomski institut, Beograd.

4. Kubr, M. (1976): Management consulting - A guide to the profession, International Labour Office, Geneva.

5. Kubr, M. (1995): Kako odabrati i koristiti konsultante, Vodič za klijente, (Prevod), Ekonomski institut, Beograd.

6. Lundberg, G., C. (1990): Towards a Manager's Model for Initiating Change Projects, JOCM, 1/1990.

7. Mihailović, B. (2011): Razvoj konsultantskih usluga u Srbiji i njihov uticaj na performanse preduzeća u agrokompleksu, Institut za ekonomiku poljoprivrede, Beograd. 
8. Petrović, Ž., Čikić, J. (2005): Savetodavstvo kao činilac ruralnog razvoja Srbije, Međunarodni naučni skup Multifunkcionalna poljoprivreda i ruralni razvoj, decembar, 2005, IEP, Beograd, str. 354-362.

9. Smernice za izbor konsultanata za sistem menadžmenta kvalitetom i korišćenje njihovih usluga, JUS ISO 10019, Standard Srbije i Crne Gore, 2005.

10. Sajfert, Z., Lazić, J., Cvijanović, J. (2008): Struktura životnih ciljeva menadžera $i$ preduzetnika u Srbiji, Industrija, br. 2/2008, Ekonomski institut, Beograd, str. 34-54.

\title{
FAKTORI IZBORA KONSULTANATA U AGROKOMPLEKSU SRBIJE
}

\section{Branko Mihailovićs, Boban Birmančević ${ }^{6}$, Miloje Obradović7}

\begin{abstract}
Apstrakt
Izboru konsultanta treba posvetiti posebnu pažnju, tim pre što u Srbiji, dakle i u njenom agrokompleksu, informisanost o kriterijima za izbor konsultantskih usluga nije na naročito visokom nivou. U samom istraživanju pošlo se od pretpostavke zasnovane na skromnom iskustvu i obaveštenosti stečene praćenjem stručne literature, ali sa dozom skepse, pa je pitanje bitnosti pojedinih kriterijuma izbora konsultanta postavljeno u obliku hipoteze, kako bi se utvrdilo pravo stanje u ovoj oblasti. Determinisanje osnovnih faktora izbora konsultanata u Srbiji nameće se po prirodnom pravu. Proces izbora konsultanta počinje definisanjem zahteva konsultantskog zadatka i kriterijuma uspešnosti zadatka. Ovim procesom se obično dolazi i do popisa referenci koje bi konsultant trebalo da ima.
\end{abstract}

Ključne reči: kriterijumi izbora konsultanta, konsultantske organizacije, sistem menadžmenta kvalitetom, agrokompleks.

5 Dr Branko Mihailović, naučni saradnik, Institut za ekonomiku poljoprivrede, 11060 Beograd, Volgina 15, Srbija, Telefon: +381 1129728 58, E-mail: brankomih@neobee.net

6 Boban Birmančević, M.Sc.ecc, Telekom Srbija a.d., Koordinator Izvršne jedinice Šabac, Regija Beograd, Izvršna jedinica Šabac, Karađorđeva 10, 15000 Šabac, Telefon: +381 64 65110 00, E-mail: bobanb@telekom.rs

7 Doc. dr Miloje Obradovic, Fakultet za inžinjerski menadžment, Bulevar Vojvode Misica 43, 11000 Beograd, Srbija, Telefon: +381 6482343 66, E-mail: mobradovic@slglasnik.com 